\begin{tabular}{|c|c|c|}
\hline$\approx$ & $\begin{array}{c}\text { Klinikal Sains } 9(1)(2021) \\
\text { JURNAL ANALIS KESEHATAN } \\
\text { KLINIKAL SAINS }\end{array}$ & KLNNKALSANSS \\
\hline $\begin{array}{l}\text { UNIVERSITAS } \\
\text { ABDURRAAB }\end{array}$ & http://jurnal.univrab.ac.id//index.php/klinikal & 불믐당 \\
\hline
\end{tabular}

\title{
PENGGUNAAN OBAT ANTIDIABETES PADA PASIEN RAWAT INAP DI RUMAH SAKIT HARAPAN PEMATANGSIANTAR
}

\author{
Shofian Syarifuddin, Ricard F. Marpaung, Pinondang Hotria \\ Prodi Farmasi, Fakultas Kesehatan, Universitas Efarina, Prodi Keperawatan, Fakultas Kesehatan, \\ Universitas Efarina, Prodi Ilmu Kesehatan Masyarakat, Fakultas Kesehatan, Universitas Efarina \\ Alamat: Jalan Pdt. J. Wismar Saragih No.01 Pematangsiantar-Sumatera Utara \\ Email: shofianunefa78@goid, \\ Email: ricardfredrik.marpaung@vahoo.co/id, \\ Email: pinondang_aja@yahoo.id
}

\section{Info Artikel Abstrak}

Sejarah Artikel:

Diterima Mei 2021 Disetujui Juni 2021 Dipublikasikan Juni 2021

Keywords:

Diabetes mellitus, antidiabetic, evaluation rationality, Harapan Hospital.
Insiden penyakit Diabetes melitus (DM) terus semakin meningkat, DM merupakan masalah kesehatan global dimana pada tahun 2000 penderita DM di dunia mencapai 346 juta orang, dan diperkirakan pada tahun 2025 akan terus naik hingga mencapai 380 juta jiwa. Indonesia memiliki jumlah penderita DM sebesar 8,4 juta orang pada tahun 2000 , dan merupakan peringkat keempat negara dengan prevalensi diabetes terbanyak di dunia. Tujuan penelitian ini adalah untuk mengetahui pola penggunaan obat antidiabetes di RSU Harapan Kota Pematangsiantar periode Januari-Maret 2020 serta mengevaluasi rasionalitas penggunaan obat antidiabetes yang meliputi ketepatan indikasi, tepat dosis, tepat obat, tepat pasien, dan tepat cara pemberian. Penelitian ini berupa penelitian survei dengan metode retrospektif, desain yang digunakan adalah cross sectional, pengumpulan data dilakukan untuk mendapatkan gambaran penggunaan obat antidiabetes pada pasien rawat inap di RSU Harapan Pematangsiantar periode Januari-Maret 2020. Hasil penelitian yang dilakukan di RSU Harapan Kota Pematangsiantar periode Januari-Maret 2020 menunjukkan bahwa pasien perempuan lebih banyak menderita diabetes melitus dibandingkan dengan lakilaki, jumlah perempuan 25 pasien $(55,6 \%)$ dan laki-laki 20 pasien $(44,4 \%)$. Distribusi pemakaian obat antidiabetes yang tertinggi adalah Glimepiride pemberian tunggal yaitu 11 peresepan $(24,4 \%)$ dan kombinasi yang tertinggi adalah Glimepiride dengan Metformin 5 peresepan $(11,1 \%)$. Hasil evaluasi rasionalitas menyatakan bahwa pemakaian obat antidiabetes telah tepat indikasi, tepat dosis, tepat obat, tepat pasien, dan tepat cara pemberian.

Kata Kunci: Diabetes melitus, antidiabetes, evaluasi rasionalitas, RSU Harapan.

\section{Abstract}

The incidence of diabetes mellitus (DM) are increasing continuously, DM is a global health problem where in 2000 people with DM in the world reached 346 million, and it was estimated that in 2025 will continue to increase to reach 380 million. Indonesia had 8.4 million people with DM in 2000, and it was the fourth country with the highest prevalence of diabetes in the world. The purpose of this 


\begin{abstract}
study was to determine the pattern of antidiabetic at Harapan Hospital, Pematangsiantar City for the January-March 2020 period and evaluate the rationality of theantidiabetic use which include the correct indication, the right dose, the right drug, the right patient, and the right way of administration. This research was a survey research with a retrospective method, the design used was cross sectional, data collection was carried out to get an overview of the antidiabetic use inpatients at Harapan Pematangsiantar General Hospital for the period January-March 2020. The results of the research conducted at Harapan Hospital Pematangsiantar City for the January-March 2020 period showed that more female patients suffer from diabetes mellitus than men, the number of female were 25 (55.6\%) and male were 20 (44.4\%). The distribution of the highest of antidiabetic use was Glimepiride single administration with 11 prescriptions (24.4\%) and the highest combination were Glimepiride and Metformin with 5 prescriptions $(11.1 \%)$. The results of the rationality evaluation state that the antidiabetic use had the right indication, the right dose, the right drug, the right patient, and the right way of administration.
\end{abstract}

Keywords: Diabetes mellitus, antidiabetic, evaluation of rationality, Harapan Hospital.

Jalan Pdt. J. Wismar Saragih No.01 Pematangsiantar- Sumatera Utara

Email: shofianunefa78@go.id,

\title{
PENDAHULUAN
}

Insidensi penyakit Diabetes melitus (DM) semakin meningkat, DM merupakan masalah kesehatan global dimana pada tahun 2000 penderita DM di dunia mencapai 346 juta orang, dan diperkirakan pada tahun 2025 akan terus naik hingga mencapai 380 juta jiwa (WHO, 2011). Indonesia memiliki jumlah penderita DM sebesar 8,4 juta orang pada tahun 2000, jumlah ini juga diperkirakan akan meningkat hingga tiga kali lipat pada tahun 2030. Indonesia merupakan peringkat keempat negara dengan prevalensi diabetes terbanyak di dunia setelah negara India, Cina dan (Hilary King et al, 2004).

Populasi penduduk usia lanjut yang semakin bertambah serta perubahan gaya hidup, mulai dari pola makan dan jenis makanan yang dikonsumsi sampai berkurangnya aktifitas fisik menyebabkan terjadinya peningkatan kasus DM, terutama mulai terjadi di usia dewasa pada seluruh golongan status sosial-ekonomi (Zahtamal dkk, 2007). Jumlah penderita diabetes melitus yang terus menerus mengalami peningkatan ini, menuntut pemerintah Indonesia untuk senantiasa tanggap terhadap penanganan dan pengobatan kasus DM.

Manifestasi klinis diabetes melitus berhubungan dengan kelainan metabolik defisiensi dan/atau resistensi insulin. Pasien yang mengalami defisiensi dan/atau resistensi insulin tidak dapat mempertahankan kadar glukosa plasma secara normal, atau terjadi toleransi glukosa 
setelah mengkonsumsi karbohidrat. Jika hiperglikemia yang terjadi berat dan melebihi ambang ginjal, maka dapat menyebabkan glikosuria. Glikosuria akan mengakibatkan diuresis osmotik yang meningkatkan pengeluaran urin (poliuria) serta menimbulkan rasa haus (polidipsia). Glukosa akan dikeluarkan bersama dengan urin, sehingga pasien mengalami keseimbangan kalori negatif dan berat badan menjadi turun. Kehilangan kalori ini menimbulkan rasa lapar yang semakin meningkat (polifagia). Selain itu juga menyebabkan pasien menjadi sering merasa lelah dan mengantuk (Price dan Wilson, 2005).

Penatalaksanaan penyakit DM memerlukan penanganan terapi yang multidisiplin, mencakup terapi non farmakologis dan terapi farmakologis (Anonim, 2005). Terapi farmakologis pada prinsipnya diberikan jika penerapan terapi non farmakologis yang telah dilakukan tidak mampu mengendalikan kadar glukosa darah plasma menjadi normal kembali (Subardi dan Yunir, 2006).

Obat antidiabetes yang digunakan dalam penatalaksanaan diabetes melitus, berdasarkan mekanisme kerja obat, secara umum diklasifikasikan menjadi dua jenis, yaitu Insulin dan obat antidiabetes oral. Insulin merupakan suatu hormon yang mengandung polipeptida, dihasilkan oleh sel- $\beta$ dari pulau Langherns pada pankreas (Rimbawan dan Siagin, 2004). Obat Insulin dan analognya menurunkan kadar glukosa dalam darah dengan menstimulasi uptake glukosa dan menghambat produksi glukosa hepatik. Insulin juga menghambat lipofisis di jaringan adiposit, menghambat proteolisis serta meningkatkan sintesa protein (Kristina, 2005). Sediaan insulin ada 3 jenis yaitu insulin kerja singkat (short-acting), insulin kerja sedang (intermediate-acting) dan insulin kerja panjang (long acting) (Anonim, 2008).

Obat antidiabetes oral diberikan jika penatalaksanaan DM melalui terapi non farmakologis berupa pengaturan pola makan, melakukan aktifitas fisik dan penurunan berat badan, belum mampu mencapai sasaran terapi diabetes pada kadar glukosa darah yang normal (Soegondo dkk, 2005). Obat antidiabetes oral dapat memberikan manfaat terapi pada pengobatan pasien diabetes melitus tipe II yang kadar glukosa darahnya tidak dapat diturunkan dengan terapi non farmakologis. Pasien yang mungkin memiliki respon terhadap obat-obat antidiabetes oral adalah pasien yang menderita penyakit diabetes melitus setelah berumur kira-kira 40 tahun dan telah menderita selama kurang dari 5 tahun (Mycek dkk, 2001). Obat antidiabetes oral, berdasarkan dari mekanisme kerja obat, diklasifikasikan menjadi tiga golongan yaitu golongan obat yang merangsang sekresi insulin (insulin secretagogue) seperti golongan obat sulfonilurea dan glinid, meningkatkan sensitivitas hormon insulin (Insulin Sensitizing) seperti biguanid dan tiazolidindion serta golongan penghambat enzim alfa Glukosidase seperti acarbose. 
Penyakit DM yang tidak terkendali sering menimbulkan komplikasi seperti penyakit stroke, jantung, gagal ginjal, kebutaan, nefropati, luka gangren, bahkan ada yang harus menjalani amputasi (Annisa, 2004). Berdasarkan uraian diatas, maka diperlukan evaluasi mengenai rasionalitas penggunaan obat antidiabetes.

\section{METODE}

Penelitian yang dilakukan merupakan penelitian survei (observasional) dengan metode retrospektif, dimana data yang diambil merupakan data yang lalu berdasarkan dari rekam medis pasien. Desain yang digunakan dalam penelitian adalah cross sectional, pengumpulan data untuk mendapatkan gambaran rasionalitas penggunaan obat antidiabetes pada pasien rawat inap di RSU Harapan Kota Pematangsiantar pada periode waktu tertentu.

Analisa dilakukan secara deskriptif tentang gambaran rasionalitas penggunaan obat antidiabetes meliputi ketepatan indikasi, pasien, jenis obat, regimen dosis, dan cara pemberian. Pengambilan data dilaksanakan pada bulan September 2020 di Instalasi Rekam Medis RSU Harapan Kota Pematangsiantar. Populasi dalam peneltian adalah seluruh pasien dewasa terdiagnosa DM yang dirawat di Ruang Rawat Inap RSU Harapan Pematangsiantar pada periode Januari-Maret 2020. Sampel dalam penelitian ini adalah seluruh populasi yang memenuhi kriteria inklusi dan tidak memenuhi kriteria eksklusi. Kriteria inklusi penelitian adalah pasien dewasa, pasien rawat inap terdiagnosa diabetes melitus seluruh tipe yang merupakan pasien RSU Harapan Pematangsiantar periode Januari-Maret 2020, sedangkan kriteria eksklusi dalam penelitian adalah pasien dengan data rekam medis yang tidak lengkap atau hilang.

\section{HASIL DAN PEMBAHASAN}

\section{Karakteristik Pasien}

Karakteristik pasien meiputi jenis kelamin dan usia pasien yang dijadikan sampling dalam penelitian. Jumlah populasi pasien yang menderita diabetes mellitus di Rumah Sakit Umum (RSU) Harapan Pematangsiantar selama periode Januari-Maret 2020 sebanyak 135 pasien dan yang memenuhi kriteria inklusi merupakan sampling dalam penelitian ini sebanyak 45 pasien. Karakteristik pasien dapat dilihat pada Tabel 1 berikut ini. 
Tabel 1 Karakteristik Pasien DM di RSU Harapan periode Januari- Maret 2020 (n=45).

\begin{tabular}{llcc}
\hline No. & \multicolumn{1}{c}{ Jenis Kateristik } & Jumlah & $\begin{array}{c}\text { Persentase } \\
(\boldsymbol{\%})\end{array}$ \\
\hline 1 & $\begin{array}{l}\text { Jenis Kelamain } \\
\text { Laki-laki }\end{array}$ & 20 & 44,4 \\
& Perempuan & 25 & 55,6 \\
\hline $2 \quad$ Usia & & \\
& 18-45 Thn & 4 & 8,9 \\
& 46-60 Thn & 20 & 44,4 \\
& $<60$ Thn & 21 & 46,7
\end{tabular}

Berdasarkan Tabel 1 dapat dilihat bahwa pasien yang menderita DM di RSU Harapan periode Januari-Maret 2020 lebih banyak perempuan dibandingkan dengan laki-laki, dengan jumlah perempuan sebanyak 25 pasien $(55,6 \%)$ dan laki-laki sebanyak 20 pasien $(44,4 \%)$. Hasil ini sama dengan penelitian yang dilakukan di RUMKITAL Dr. Mintohardjo sebanyak 15 orang (63\%) perempuan dan sebanyak 9 orang (37\%) laki-laki. Berdasarkan data-data tersebut, menunjukkan bahwa tingkat resiko terdiagnosis DM pada jenis kelamin peempuan lebih tinggi dibandingkan dengan jenis kelamin laki-laki, Penelitian ini juga sesuai dengan data yang disampaikan oleh Kementerian Kesehatan yang menunjukkan prevalensi penyakit DM terjadi kecenderungan yang lebih tinggi pada jenis kelamin perempuan, daerah perkotaan dan masyarakat dengan tingkat pendidikan yang lebih tinggi (Kemenkes, 2013).

Berdasarkan usia dapat dilihat bahwa pasien yang menderita DM periode Januari-Maret 2020 di RSU Harapan Pematangsiantar yang tertinggi aalah pasien lansia berusia <60 Tahun sebanyak 21 pasien (46,7\%), kemudian diikuti pasien berusia 46-60 Tahun sebanyak 20 pasien $(44,4 \%)$ dan pasien berusia 18-45 Tahun sebanyak 4 pasien (8,9\%). Berdasarkan usia tersebut, dapat diketahui bahwa pada usia 46 yaitu masa lansia awal merupakan usia yang paling banyak terdiagnosis DM. Pada masa lansia awal, terjadi kecenderungan kenaikan kadar glukosa darah dan gangguan toleransi darah, hal ini menyebabkan prevalensi DM pada masa lansia awal menjadi semakin meningkat. Proses-proses menua terjadi mulai usia 30 tahun, tubuh akan mengalami perubahan-perubahan pada anatomis, fisiologis, dan biokimia. Proses perubahan yang terjadi mulai dari sel, jaringan dan organ tubuh yang akhirnya mempengaruhi fungsi homeostatis dari organ tubuh tersebut, termasuk organ pankreas yang berperan dalam sekresi insulin mengalami perubahan pada sel beta pankreas sehingga mempengaruhi kadar glukosa darah (Goldberg dan Coon dalam Rochman, 2006). 


\section{Distribusi Pemakaian Obat Antidiabetes}

Distribusi pemakaian obat antidiabetes di RSU Harapan periode Januari-Maret 2020 dapat dilihat pada Tabel 2.

Tabel 2 Distribusi Pemakaian Obat Antidabetes di RSU Harapan periode Januari-Maret 2020.

\begin{tabular}{llcc}
\hline No. & \multicolumn{1}{c}{ Nama Antidiabetes } & Jumlah & $\begin{array}{c}\text { Persentase } \\
(\boldsymbol{\%})\end{array}$ \\
\hline 1 & Tunggal (Oral) & 11 & 24,4 \\
& Glimepiride & 4 & 8,9 \\
& Gliquidon & 3 & 6,7 \\
& Metformin & 1 & 2,2 \\
\hline Kombligyze syr. & & \\
\hline 2 & Tunggal (Parenteral) & 7 & 15,6 \\
& Apidra & 2 & 4,4 \\
& Novorapid & 2 & 4,4 \\
& Humalog lispro & 1 & 2,2 \\
\hline Humalog mix & & \\
\hline Obat kombinasi & 5 & 11,1 \\
& Glimepiride + Metformin & 2 & 4,4 \\
& Apidra + Lantus & 2 & 4,4 \\
& Lantus + Humalog lispro & 2 & 4,4 \\
& Gliquidon + Lantus & 1 & 2,2 \\
& Novorapid + Lantus & 1 & 2,2 \\
\hline
\end{tabular}

Berdasarkan Tabel 2 dapat dilihat distribusi pemakaian obat antidiabetes mellitus di RSU Harapan Pematangsiantar periode Januari-Maret 2020 yang tertinggi adalah glimepiride pemberian tunggal sebanyak 11 peresepan $(24,4 \%)$, kemudian diikuti injeksi apidra pemberian tunggal sebanyak 7 peresepan $(15,6 \%)$, kombinasi glimepiride dengan metformin sebanyak 5 peresepan $(11,1 \%)$, gliquidon pemberian tunggal sebanyak 4 peresepan $(8,9 \%)$, metformin pemberian tunggal sebanyak 3 peresepan (6,7\%), humolog lispro pemberian tunggal, novorapid pemberian tunggal, kombinasi apidra dengan lantus, kombinasi lantus dengan humolog lispra dan kombinasi gliquidon dengan lantus masing-masing 2 peresepan $(2,2 \%)$, kombligyze $\mathrm{xr}$ pemberian tunggal, humolog mix pemberian tunggal, kombinasi novorapid dengan metformin dan kombinasi sansulin dengan gliquidon masing-masing 1 peresepan $(1,1 \%)$.

Pemakaian obat antidiabetes tunggal (monoterapi) yang paling banyak diberikan kepada pasien berdasarkan data adalah adalah glimepiride (24,3\%) dan injeksi apidra $(15,6 \%)$. Penatalaksanaan terapi DM di Indonesia, ditemukan bahwa golongan sulfonilurea merupakan abat antidiabetes oral yang paling banyak digunakan, dan insulin rapid acting (kerja cepat) merupakan kategori insulin yang paling banyak digunakan. Golongan Sulfonilurea seperti glimepiride merupakan obat pilihan (drug of choice) dalam terapi DM pada pasien dewasa dengan berat badan normal dan kurang serta tidak pernah mengalami ketoasidosis sebelumnya, 
disamping itu golongan sulfoniluea memiliki efek samping obat yang ringan dan frekuensi kejadian efek sampan obat juga rendah, seperti gangguan saluran cerna serta gangguan susunan saraf pusat (Handoko dan Suharto, IONI 2000). Golongan sulfonilurea merupakan obat pilihan utama setelah metformin dalam pemberian monoterapi (Dipiro, 2008).

Pemakaian obat antidiabetes injeksi berupa insulin berdasarkan data yang paling banyak digunakan ialah injeksi apidra. Penggunaan insulin dalam penatalaksanaan pengobatan DM, diberikan jika kondisi pasien DM memiliki kadar glukosa darah yang sangat tinggi, pasien yang mengalami komplikasi gagal ginjal kronik, ataupun jika pemberian kombinasi antidiabetes oral tidak menunjukkan penurunan glukosa darah yang signifikan. Pasien yang memiliki kadar glukosa yang tinggi biasanya telah mengalami komplikasi, atau cenderung mengalami komplikasi, oleh sebab itu dalam penatalaksanaannya sebaiknya diberikan antidiabetes golongan insulin, jika kadar glukosa darah sudah relatif stabil, maka dapat dilakukan evaluasi terhadap penggunaan antidiabetes oral. Injeksi apidra banyak digunakan dalam pengobatan DM disebabkan karena memiliki kerja yang cepat (rapid acting) sehingga dapat memberikan efek penurunan kadar glukosa postprandial yang lebih cepat dibandingkan insulin reguler serta memiliki keunggulan dalam hal penyuntikannya (ACCP, 2013).

Pada keadaan tertentu diperlukan terapi kombinasi dari beberapa golongan obat antidiabetes, seperti kombinasi dua atau tiga golongan obat antidiabetes oral, kombinasi obat antidiabetes oral dengan insulin atau kombinasi insulin short acting dengan long acting. Data pada Tabel 2 menunjukkan pemakaian kombinasi beberapa obat antidiabetes oral yang paling banyak digunakan ialah kombinasi antara metformin dengan glimepirid sebanyak $11,1 \%$. Kombinasi obat Antidiabetes oral dengan Insulin dan kombinasi insulin short acting dengan long acting masing-masing sebanyak $4,4 \%$.

Glimepirid merupakan obat yang termasuk ke dalam golongan sulfonilure. Glimepirid memiliki mekanisme kerja menstimulasi eksreksi insulin sedangkan metformin bekerja menurunkan kadar glukosa darah dengan cara mengurangi glukoneogenesis hepatik, meningkatkan sensitifitas insulin, serta mengurangi absorbsi glukosa pada saluran cerna. Kedua golongan obat tersebut memiliki mekanisme kerja yang saling bersinergis dalam menurunkan kadar glukosa darah, menurunkan glukosa darah lebih banyak daripada pengobatan tunggal masing-masing, baik pada dosis maksimal keduanya maupun pada kombinasi dosis rendah, oleh sebab itu kombinasi dari kedua golongan obat tersebut merupakan kombinasi yang rasional dalam pentalaksanaan pengobatan DM. Berdasarkan hasil peneltian UKPDS (United Kingdom Prospective Diabetes Study) dimana hanya 50\% pasien DM tipe 2 yang kemudian dapat dikendalikan dengan pengobatan tunggal metformin atau sulfonilurea sampai dosis maksimal, maka pemberian kombinasi kedua golongan antidiabetes oral ini sudah dapat dianjurkan untuk 
diberikan sejak awal pengobatan DM tipe 2 (Soegondo, 2005).

Selain pemberian kombinasi beberapa golongan obat antidiabetes oral, kombinasi antara obat antidiabetes oral dengan injeksi insulin juga banyak digunakan dalam pengobatan DM tipe 2, terutama terhadap pasien yang belum mencapai sasaran dalam penurunan kadar glukosa darah dengan penggunaan obat antidiabetes oral dosis maksimal atau pasien yang memiliki kontraindikasi dari obat tersebut. Kombinasi antidiabetes oral dengan insulin basal (insulin kerja cepat atau insulin kerja panjang) yang diberikan pada malam hari menjelang tidur merupakan kombinasi obat antidiabetes oral dengan injeksi insulin yang banyak dipergunakan dalam penatalaksanaan penyakit DM (Sudoyo, 2006)

Kombinasi beberapa kategori obat antidiabetes golongan insulin juga dapat diberikan dalam peantalaksanaan DM, terutama kombinasi golongan insulin yang memiliki kerja cepat (rapid acting) dengan golongan insulin yang memiliki kerja panjang (long acting). Insulin golongan rapid acting memiliki mula kerja (onset of action) yang cepat, dapat menurunkan kadar glukosa darah dalam waktu 20 menit setelah pemberian. Kelemahan insulin rapid acting memiliki durasi kerja yang singkat, oleh sebab itu kombinasi dengan insulin long acting merupakan kombinasi yang sangat baik untuk mengendailkan kestabilan kadar glukosa darah disepanjang hari (Sudoyo, 2006).

\section{Analisis Kerasionalan Obat Antidiabetes}

Menurut Kumolosari dkk (2001) tingginya angka kejadian DM serta komplikasi yang dapat ditimbulkannya, menyebabkan pentingnya penanganan DM secara tepat. Penatalaksanaan DM harus dilakukan secara rasional baik secara farmakologi maupun non farmakologi. Kerasionalan terapi dalam penatalaksanaan DM didasarkan pada ketepatan diagnosis, pemilihan obat, pemberian obat, serta evaluasi outcome terapi. Evaluasi outcome terapi merupakan suatu proses jaminan mutu yang terstruktur dan dilakukan secara terus menerus untuk menjamin agar obat-obat yang digunakan tepat, aman, dan efisien).

Penilaian rasionalitas obat merupakan aspek penilaian ketepatan pengobatan yang berhubungan dengan ketepatan indikasi, tepat obat, tepat dosis, tepat pasien, tepat cara pemberian obat, efek samping obat yang minimal serta tidak terdapat interaksi dalam pengobatan. Pengobatan yang rasional dapat dicapai apabila telah memenuhi aspek-aspek penilaian tersebut secara tepat. Penatalaksanaan DM pada pasien yang tidak memenuhi salah satu aspek penilaian tidak dapat dinyatakan pengobatan DM yang dilakukan telah rasional. (Kumolosari, dkk, 2001)

\section{Tepat Indikasi}

Menurut PERKENI (2006) tepat indikasi dalam pengobatan DM adalah ketepatan pemberian obat antidiabetes atas dasar diagnosis yang ditegakkan, sesuai dengan diagnosis yang 
tercatat di dalam data rekam medik pasien yang memiliki kadar gula darah (KGD) sewaktu $>200 \mathrm{mg} / \mathrm{dl}$. Berdasarkan hasil penelitian menunjukkan bahwa penatalaksanaan terapi DM tipe 2 di RSU Harapan Kota Pematangsiantar $100 \%$ telah tepat indikasi. Meskipun ada beberapa pasien memiliki KGD < $200 \mathrm{mg}$, tetapi pasien tersebut sudah memiliki riwayat DM.

\section{Tepat Dosis}

Salah satu aspek penilaian kerasionalan pengobatan adalah ketepatan pemberian dosis terapi. Dosis terapi pada pasien DM tipe 2 harus disesuaikan dengan kondisi pasien, terutama kadar glukosa darah pasien, serta berdasarkan besaran dosis yang sudah ditetapkan pada literatur (Drug Information Handbook). Berdasarkan hasil penilaian ketepatan dosis pada pemberian obat antidiabetes pasien DM tipe 2 rawat inap di RSU Harapan Kota Pematangsiantar, jumlah pemberian antidiabetik yang sudah tepat dosis adalah sebanyak $100 \%$. Penilaian ketepatan dosis pada pasien didasarkan pada dosis regimen yang diberikan. Seluruh pasien DM tipe 2 rawat inap RSU Harapan Kota Pematangsiantar telah mendapatkan dosis yang sesuai dengan persyaratan yang sudah ditetapkan literatur.

\section{Tepat Pasien}

Aspek penilaian kerasionalan obat yang tepat pasien dalam penelitian ini adalah pemberian obat antidiabetes yang sesuai dengan diagnosis, kondisi dan kebenaran obat yang ditujukan untuk pasien tersebut sesuai dengan rekam medis pasien, maka hasil penelitian mendapatkan $100 \%$ pemberian obat antidiabetes telah tepat pasien.

\section{Tepat Obat}

Aspek penilaian ketepatan obat yaitu kesesuaian dalam pemilihan obat antidiabetes diantara beberapa golongan obat antidiabetes yang mempunyai indikasi untuk penatalaksanaan DM tipe 2 sesuai dengan literatur standar dan disesuaikan dengan riwayat pengobatan pasien yang telah digunakan sebelumnya.

Berdasarkan guideline Joslin's Diabetes Melitus pada penatalaksanaan DM, metformin merupakan pilihan obat pada awal terapi (kecuali ada kontraindikasi) karena golongan obat ini tidak menyebabkan peningkatan berat badan dan efek hipoglikemia, memiliki efek samping yang ringan, dapat diterima dengan baik, serta memiliki harga yang murah. Sulfonilurea merupakan pilihan jika metformin dikontraindikasikan dan tidak memiliki berat badan berlebih. Jika pengobatan belum mencapai sasaran penurunan kadar glukosa darah yang diinginkan, maka pengobatan dilakukan dengan terapi kombinasi antara metformin dengan obat antidiabetes oral lainnya seperti golongan sulfonilurea. Pemberian antidiabetes lain juga dapat diberikan jika metformin memiliki kontra indikasi. Insulin diberikan pada pasien dengan gejala sekunder akibat hiperglikemia, untuk memberikan pengobatan yang lebih efektif. Pemberian insulin dapat dimulai dengan golongan insulin basal. Jika pentalaksanaan non farmakologis seperti perubahan 
gaya hidup, kemudian ditambah terapi farmkaologis dengan pemberian metformin, dan sulfonilurea atau insulin basal tidak menurunkan kadar glukosa darah sesuai dengan yang diinginkan, langkah selanjutnya harus dimulai dengan intensifikasi terapi insulin yaitu pemberian tamabahan injeksi insulin kerja pendek dan cepat yang diberikan sebelum makan untuk menurunkan kadar glukosa darah postprandial. Jika insulin intensif telah dimulai, obatobatan secretagok insulin seperti golongan sulfonilurea atau glinid harus dihentikan atau diturunkan secara perlahan sampai dihentikan, dengan pertimbangan tidak bersifat sinergik (Dipiro, et al, 2008).

Dari hasil data deskriptif diketahui bahwa obat antidiabetik oral yang paling banyak diberikan adalah golongan sulfonylurea yaitu glimepiride, hal ini berdasarkan pertimbangan efek samping metformin yang menyebabkan gangguan lambung, sementara pasien telah mengalami dispepsia, maka pilihan pengganti obat oral metformin adalah glimepiride. Berdasarkan hal tersebut dikategorikan obat yang diberikan terhadpa pasien merupakan obat yang tepat. Hasil evaluasi menunjukkan bahwa $100 \%$ pasien diberikan obat antidiabetes yang sesuai riwayat pengobatan dan algoritma pemilihan obat antidiabetes.

\section{Tepat Cara Pemberian Obat}

Cara pemberian obat yang tepat merupakan aturan penggunaan obat yang harus diperhatikan oleh pasien dalam memberikan pengobatan yang rasional. Aturan penggunaan obat yang diperhatikan antara lain waktu penggunaan obat seperti waktu pemberian obat sebelum atau sesudah makan, frekuensi dan rute pemberian obat. Berdasarkan hasil evaluasi pasien diabetes mellitus di RSU Harapan Pematangsiantar periode Januari-Maret 2020 cara pemberian obat $100 \%$ diberikan dengan tepat. Glimepiride, metformin dan gliquidon diberikan sebelum makan dengan cara peroral, sediaan injeksi insulin diberikan 15 menit sebelum makan dengan cara intra muskular. Glimepiride diberikan dengan frekunsi 1 x24 jam, Insulin short acting diberikan dengan frekuensi/8 jam dan long acting diberikan pada malam hari dengan frekuensi/24 jam.

\section{SIMPULAN}

Hasil evaluasi rasionalitas menyatakan bahwa pemakaian obat antidiabetes di RSU Harapan Pematangsiantar periode Januari-Maret 2020 telah tepat indikasi, tepat obat tepat dosis, tepat pasien dan tepat cara pemberian. 


\section{UCAPAN TERIMA KASIH}

Ucapan terima kasih kami sampaikan kepada seluruh keluarga, rekan dan teman sejawat Dosen di Fakultas Kesehatan Universitas Efarina, Ketua LPPM serta pihak-pihak terkait yang telah membantu dan bekerjasama demi kelancaran penelitian ini.

\section{REFERENSI}

American College of Clinical Pharmacy. 2013. Pharmacotherapy Review Programfor Advanced Clinical Pharmacy Practice. and Impaired Glucose Tolerance in Indonesia.

Andayani, Tri Murti. 2006. Analisis Biaya Terapi Diabetes melitus di Rumah Sakit Dr. Sardjito Yogyakarta. Majalah Farmasi Indonesia 17 (3) 2006.

Annisa. 2004. Komplikasi Diabetes. Terdapat dalam http:/annisalaboratories.com/komplikasi/diabetes.

Arifin, Ibrahim, Prasetyaningrum, Erna, Murti, Tri. Evaluasi Kerasionalan Pengobatan Diabetes Melitus Tipe 2 Pada Pasien Rawat Inap Di Rumah Sakit Bhakti Wira Tamtama Semarang Tahun 2006. Jurnal Ilmu Farmasi dan Farmasi Klinik Vol . 4 No. 1 Juni 2007. Hal 23-29.

Badan Penelitian dan Pengembangan Kesehatan Departemen Kesehatan, Republik Indonesia. 2008. Riset Kesehatan Dasar (RISKESDAS) Laporan Nasional 2007. Jakarta : Kementerian Kesehatan RI.

Brunner \& Suddarth. 2002. Keperawatan Medikal Bedah Edisi 8. Jakarta : EGC. Chandra, Budiman. 2008. Metodologi Penelitian Kesehatan. Jakarta : Penerbit Buku Kedokteran EGC.

Cheng AYY, Zinman B, han CR. 2005. Joslin's Diabetes Melitus. 4 th. Lipincott Williams \& Wilimns. Philadelphia.

Davis, N. Stephen et al. Exploring the Substitution of Exenatide for Insulin in Patients With Type 2 Diabetes Treated With Insulin in Combination With Oral Antidiabetes Agents. Diabetes Care Volume 30 Number 11. November 2007.

Departemen Farmakologi dan Terapeutik Fakultas Kedokteran Universitas Indonesia. 2007. Farmakologi dan Terapi. Jakarta : Gaya Baru.

Direktorat Bina Farmasi Komunitas dan Klinik Direktorat Jenderal Bina Kefarmasian dan Alat Kesehatan Departemen Kesehatan RI 2005.

Handoko, T., dan Suharto B. 1995. Insulin Glukagon dan Antidiabetik Dalam Farmakologi dan Terapi, edisi IV, editor: Sulistia G. Ganiswara, Jakarta, Gaya Baru. Halaman 469, 471472.

Hardman, Joel G, Lee E. Limbird. Goodman \& Gilman Dasar Farmakologi Terapi. Edisi 10 Volume 4. Jakarta : EGC. 
Hilary, King, Sicree Richard, Green Anders, Roglic Gojka, Wild Sarah. 2004. Global Prevalence of Diabetes: Estimates for the year 2000 and projections for 2030.

Diabetes care vol 27 number $5: 1047$ - 1053

http://binfar.kemkes.go.id/v2/wp-content/uploads/2014/02/PC_DM.pdf diakses pada 14 Agustus 2020.

International Diabetes Federation. 2013. IDF Diabetes Atlas Sixth Edition. Belgia : IDF. Hal 13.

Joseph, T. Dipiro, Robert L. Talbert, Gary C. Yee, Gry R. Matzkee, Barbara G. Wells, L. Michael Polsey (Eds.). 2008. Pharmacotherapy A Pathophysiologic Approach. Edisi ke7, New York : Mc Graw-Hill Medical Publishing Division.

Keputusan Menteri Kesehatan Republik Indonesia Nomor 1197/MENKES/SK/X/2004 tentang Standar Pelayanan Rumah Sakit.

Keputusan Menteri Kesehatan Republik Indonesia Nomor 440/MENKES/SK/XII/2012.

Keputusan Menteri Kesehatan Republik Indonesia Nomor 312/MENKES/SK/IX/ 2013. Tentang Daftar Esensial Obat Nasional 2013.

King H, Aubert RE, Herman WH. 1998. Global Burden of Diabetes, 1995-2025: Prevalence, Numerical Estimates, and Projections.Diabetes Care vol. 21:1414-1431..

Kurniawan,Indra. 2010. Diabetes Melitus Tipe 2 Pada Usia Lanjut. Majalah Kedokteran Indonesia Vol 60.

Mansjoer, arief, dkk. 2001. Kapita Selekta Kedokteran Edisi ketiga Jilid Pertama.

Mihardja, Laurentia dkk. 2009. Prevalence and Determinants of Diabetes Melitus (A Part of Basic Health Research/Riskesdas). Acta Med Indones- Indones J. Intern Med.

Mycek, M.J., Harvey, R.A., dan Champe C.C. 2001. Farmakologi Ulasan Bergambar. Lippincottt's Illustrated Reviews: Farmacology. Penerjemah Azwar Agoes. Edisi II. Jakarta. Widya Medika.

Mycek, Mary J. 2001. Farmakologi Ulasan Bergambar. Jakarta : Widya Medika. Naditha Arun, Ramachandran Ambady, Snehalatha Chamukuttan, Shetty Ananth.

Samith. 2012. Trends In Prevalence of Diabetes In Asian CountriesWorld Journal of Diabetes vol 3 issue 6. Baishideng.

Nita Yunita, Yuda Ana, Nugraheni Gesnita. 2012. Pengetahuan Pasien Tentang Diabetes dan Obat Anti Diabetes Oral.Jurnal Farmasi Indonesia Vol. 6 No.1 Januari 2012: 38-47.

PERKENI. 2007. Petunjuk Praktis Terapi Insulin Pada Pasien Diabetes Melitus. Jakarta : Fakultas Kedokteran Universitas Indonesia.

Perkumpulan Endokrinologi Indonesia (PERKENI). 2011. Konsensus Pengelolaan dan Pencegahan Diabetes Melitus Tipe 2 di Indonesia. Jakarta: PERKENI. 
Price, Sylvia A. 1995. Edisi 4. Patofisiologi : Konsep Klinis Proses-Proses Penyakit. Jakarta : EGC.

Pusat Data dan Informasi Kementerian Kesehatan RI. 2011. Data dan Informasi.Jakarta : Kementerian Kesehatan RI.

Soegondo S. 2005. Prinsip Pengobatan Diabetes, Obat Hipoglikemik Oral dan Insulin. Balai Penerbit FKUI.

Sudoyo, Aru W, Dr.dr. 2006.Buku Ajar Ilmu Penyakit Dalam, Jilid III, Edisi IV. Jakarta: Pusat Penerbitan Departemen Ilmu Penyakit Dalam Fakultas Kedokteran Universitas Indonesia.

Suryabrata, S. 2010. Metodologi Penelitian. Jakarta : Rajawali Pers.

Swandari, Swestika. 2013. Penggunaan Obat Rasional (POR) 8 Tepat 1 Waspada Efek Samping. http:bppkmalang.com

Tatro, David S. 2009. Drugs Interaction Facts. Wolters Kluwer Health, Inc. San Carlos, California.

Yusmainita. 2005. Pemberdayaan Instalasi Farmasi Rumah Sakit Pemerintah (Bagian I), Medika, No 12 tahun ke XXVIII,Desember 2002, ISSN. 0216- 0910,799-801

Zahtamal, Chandra, F., Suyanto, dan Restuastuti, T. 2007. Faktor-Faktor Risiko Pasien Diabetes Melitus. Berita Kedokteran Masyara 